\title{
Protective Role of Ficus carica Extract Against Hepato-Testicular Side Effects and Genotoxicity Induced by Cisplatin
}

\author{
Maha A. Fahmy', Entesar E. Hassan ${ }^{1, *}$, Noha E. Ibrahim², Emad M. Hassan³, Zeinab M. Hassan4, Enayat A. \\ Omara $^{5}$
}

Maha A. Fahmy ${ }^{1}$, Entesar E. Hassan ${ }^{1, *}$, Noha E. Ibrahim², Emad M. Hassan ${ }^{3}$, Zeinab M. Hassan ${ }^{4}$, Enayat A. Omara ${ }^{5}$

'Genetics and Cytology Department, Genetic Engineering and Biotechnology Division, National Research Centre, Dokki, Cairo, EGYPT.

${ }^{2}$ Microbial Biotechnology Department, Genetic Engineering and Biotechnology Division, National Research Centre, Dokki, Cairo, EGYPT.

${ }^{3}$ Medicinal and Aromatic Plants Research Department, National Research Centre, Dokki, Cairo, EGYPT.

${ }^{4}$ Natural Compounds Chemistry Department, National Research Centre,Dokki, Cairo, EGYPT

${ }^{5}$ Pathology Department, National Research Centre, Dokki, Cairo, EGYPT.

\section{Correspondence}

Entesar E. Hassan

Genetics and Cytology Department, Genetic Engineering and Biotechnology Division, National Research Centre, Dokki, Cairo, EGYPT.

E-mail: entesarhassen@yahoo.com History

- Submission Date: 14-02-2020.

- Review completed: 03-03-2020;

- Accepted Date: 26-03-2020.

DOI : 10.5530/pj.2020.12.96

Article Available online

http://www.phcogj.com/v12/i3

\section{Copyright}

(C) 2020 Phcogj.Com. This is an openaccess article distributed under the terms of the Creative Commons Attribution 4.0 International license.

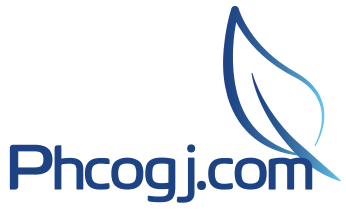

\begin{abstract}
Objective: The present work investigated the protective effect of Ficus carica (common fig) leaves methanol extract against genotoxicity and testicular damage of cisplatin (CP) and identified some of its active ingredients. Methods: Seven main groups were investigated as follows: I. control negative, II. Control plant $(600 \mathrm{mg} / \mathrm{kg}$ fig, orally), III, IV. Control positive (treated i.p with 10 and $15 \mathrm{mg} / \mathrm{kg} \mathrm{CP),} \mathrm{V-VII.} \mathrm{groups} \mathrm{treated} \mathrm{with} \mathrm{fig}(200,400$ and $600 \mathrm{mg} /$ $\mathrm{kg})+$ Cisplatin $(15 \mathrm{mg} / \mathrm{kg})$. Results: Ficus carica alleviated the destructive effects of CP in the testis, liver and bone marrow due to the presence of high amount of flavonoids and phenolic compounds. Also it has a normal effect in the tested parameters as compared with the control negative. Chromatographic investigation resulted in the identification of 6 compounds: Catechin, Luteolin-8-C- $\beta-D$ glucopyranoside, Quercetin, Quercetin-3-O- $\beta$-d-glucopyranoside, Chlorogenic acid and Kaempferol-3-O- $\beta$-D-glucopyranoside. In bone marrow cisplatin induced significant percentage of chromosome abnormalities, micronuclei in polychromatic erythrocytes and toxicity to cells. On the contrary the two tested doses of cisplatin had a normal effect on spermatocyte chromosomes (germ cells). The dose $15 \mathrm{mg} / \mathrm{kg}$ induced an overexpression of the liver genes NF-kB and iNOS as indicated by real-time PCR. Different forms of histopathological alterations and instigation of the expression of TNF- $\alpha$ gene in the testis were detected after CP treatment. Conclusion: Ficus carica is a promising candidate rich in many bioactive constituents and can be used in combination with chemotherapeutic drugs to alleviate their destructive effects.

Key words: Cisplatin, Bone marrow, Spermatocytes, liver, Testis, Fig, Protection.
\end{abstract}

\section{INTRODUCTION}

Plant products and their secondary metabolites are generally safer and cheaper compared to synthetic drugs and could be used for the treatment of many diseases. Herbal medicine is considered nowadays the point of interest for many pharmacologists who try to produce new drugs from plant products ${ }^{1}$.

Ficus carica Linn (Moraceae) is an important plant in the genus Ficus and commonly referred to as "fig". It is one of the first plants that were cultivated in the world. Ficus carica is an important genetic resource with high nutritional and economic values. It has been used in traditional medicine for the treatment of a wide range of ailments related to digestive, endocrine, reproductive and respiratory systems. It is also used in the gastrointestinal tract, urinary tract infections and for inflammatoryrelated diseases and cancer. Phytochemical studies on fruits and leaves of fig have shown that they are rich in phenolics, organic acid and volatile compounds ${ }^{2}$. Extracts from different parts were demonstrated to possess a wide range of biological activities. Some of the most interesting therapeutic activities include: immunosuppressive ${ }^{3}$, antiinflammatory ${ }^{4}$, hepatoprotective ${ }^{5}$, hypoglycemic ${ }^{6}$ and anticancer activities ${ }^{7}$.

In the present work cisplatin is used as a positive genotoxic agent. Cisplatin $(\mathrm{CP})$ is one of the first- line anticancer drugs that has gained widespread use against various forms of human malignancies e.g testicular, ovarian and breast cancers, esophageal cancer, lung cancer, bladder cancer, head and neck cancer, brain tumors and neuroblastoma ${ }^{8}$. Cisplatin is from the platinum-based antineoplastic family of medications. It works in part by binding to DNA and inhibiting its replication'. Like other chemotherapeutic drugs, cisplatin possesses many adverse side effects in patients under its treatment including: genotoxicity ${ }^{10}$, nephrotoxicity ${ }^{8}$, liver dysfunction ${ }^{11}$ and reproductive impairment ${ }^{12}$.

The present work aimed to evaluate the possible protective effect of Ficus carica leaves methanol extract against genotoxicity and testicular damage of cisplatin. The study includes genetic and histopathological endpoints. Phytochemical studies were performed to separate and identify some of the active components of Ficus carica and their relation with the obtained results was discussed.

\section{MATERIALS AND METHODS}

\section{First part: Phytochemical studies}

Preparation and chemical investigation of Ficus carica extract

The leaves of Ficus carica were collected from Giza governorate, Egypt, in Sep. 2018, and identified by

Cite this article: Fahmy MA, Hassan EE, Ibrahim NE, Hassan EM, Hassan ZM, Omara EA. Protective Role of Ficus carica Extract Against Hepato-Testicular Side Effects and Genotoxicity Induced by Cisplatin. Pharmacogn J. 2020;12(3):645-56. 
Dr. Adel Salama. A voucher specimen is deposited at the National Research Centre herbarium, under the number of $\mathrm{F} 232$. The plant leaves were dried at room temperature and finely powdered.

\section{General experimental conditions}

Column chromatography was performed on sephadex LH-20 (Fluka) and polyamide 6S (Riedel-De Haen, Hannover, Germany). Paper chromatography Whatman No. 1 and $3 \mathrm{MM}$ were carried out using solvent systems: A (15\% AcOH) and B (n-BuOH-AcOH-H2O, 4:2:1). Mass spectra were achieved on Finnigan SS Q 700 spectrometer, $70 \mathrm{eV}$. NMR experiments were performed on a Bruker AMX 400 instrument with standard pulse sequences operating at $400 \mathrm{MHz}$ in ${ }^{1} \mathrm{H} \mathrm{NMR}$ and $100 \mathrm{MHz}$ in ${ }^{13} \mathrm{C}$ NMR. Chemical shifts are given in $\delta$ values (ppm) using tetramethylsilane as the internal standard and DMSO- $d_{6}$ as solvent at room temperature. UV spectral data was measured on a Shimadzu 240 spectrometer in $\mathrm{MeOH}$.

\section{Extraction}

Dried leaves powder of Ficus carica $(1 \mathrm{~kg})$ was extracted with $\mathrm{MeOH}$ four times in a percolator. The collected $\mathrm{MeOH}$ extracts were evaporated under vacuum $\left(40^{\circ} \mathrm{C}\right)$ to yield $152.55 \mathrm{~g}$. The $\mathrm{MeOH}$ extract was kept under cooling $\left(10^{\circ} \mathrm{C}\right)$ until analysis.

\section{Determination of total phenolics and flavonoids}

Reagents: Aluminum chloride was prepared by dissolving $2 \mathrm{~g}$ of aluminum chloride (Sigma) in $100 \mathrm{ml}$ pure methanol (HPLC). Foline reagent, saturated solution of sodium carbonate $(40 \mathrm{~g} / 100 \mathrm{ml}$ distilled water).

The determination of the total phenolic and flavonoids in the methanolic extract of Ficus carica leaves was carried out as follows, a known weight of $\mathrm{MeOH}$ extract was dissolved in $80 \%$ methanol, transferred to measuring flask $100 \mathrm{ml}$ and completed to $100 \mathrm{ml}$ with $80 \%$ methanol.

\section{Determination of total phenolic}

The total phenolic content was determined by Folin-Ciocalteu according to the method described by Meda et al. ${ }^{13}$ with some modifications. One $\mathrm{ml}$ of the sample extract was added to $7.5 \mathrm{ml}$ of redistilled water and $0.5 \mathrm{ml}$ of Folin-Ciocalteu reagent (Sigma Chemical Co.; St. Louis, Mo.; U.S.A.) was added. After 15 min equilibration, the mixture was neutralized with $1.0 \mathrm{ml}$ of $\mathrm{Na}_{2} \mathrm{CO}_{3} 40 \%$, mixed well by a vortex. After a $30 \mathrm{~min}$ reaction, the absorbance of the mixture was measured at 760 $\mathrm{nm}$. To methanol $80 \%,(8.5 \mathrm{ml}), 0.5 \mathrm{ml}$ Folin and $1 \mathrm{ml} \mathrm{Na}_{2} \mathrm{CO}_{3}$ was used as blank. Chlorogenic acid (Sigma) was used as a standard curve. Concentration of the total phenolic was determined from a standard calibration curve. The mean of three readings was used and results were expressed as milligrams of chlorogenic acid equivalent per gram of the extract $(\mathrm{mg} / \mathrm{g}$ extract).

\section{Determination of total flavonoids}

The total flavonoid content was determined according to the method adopted by Meda et al. ${ }^{13}$ (2005). Briefly, $3 \mathrm{ml}$ of the extract were mixed with $3 \mathrm{ml}$ of $\mathrm{AlCl}_{3}$ ( $2 \%$ in methanol) and the mixture was allowed to stand for $30 \mathrm{~min}$. The absorbance was measured at $415 \mathrm{~nm}$ against a blank sample which consists of $3 \mathrm{ml} \mathrm{AlCl}_{3}$ with $3 \mathrm{ml}$ methanol $80 \%$. Rutin (Sigma-Aldrich) was used as a standard and the total flavonoid content was determined using the standard curve, the mean of three readings was recorded and the total flavonoids were expressed in $\mathrm{mg}$ as rutin equivalent per $1 \mathrm{~g}$ of the extract ( $\mathrm{mg} / \mathrm{lg}$ extract).

\section{Isolation of the phenolic constituents}

The methanol extract was suspended into hot water, left overnight, filtered and was successively partitioned with methylene chloride and $n$-butanol $(\mathrm{BuOH})$ and then evaporated till dryness under vacuum (53 and $38 \mathrm{~g}$, respectively). The $\mathrm{BuOH}$ fraction was subjected to TLC and paper chromatography in two different systems; a (15\% $\mathrm{AcOH})$ and $\mathrm{B}\left(n-\mathrm{BuOH}-\mathrm{AcOH}-\mathrm{H}_{2} \mathrm{O}\right)$. The dry $\mathrm{BuOH}$ extract was uploaded on a polyamide $6 \mathrm{~S}$ column chromatography $(100 \times 5 \mathrm{~cm})$. The column was eluted with $\mathrm{H}_{2} \mathrm{O}$, and then $\mathrm{H}_{2} \mathrm{O}-\mathrm{MeOH}$ mixtures of decreasing polarity and seven fractions $(1 \mathrm{~L}$, each) were collected. The major phenolic fractions obtained were combined into two fractions after chromatographic analysis. Fraction A $(1.0 \mathrm{~g})$ was fractionated by column chromatography on sephadex LH-20 with aqueous $\mathrm{MeOH}$ $(0-80 \%)$ for elution to give compounds $1(17 \mathrm{mg}), 2(13 \mathrm{mg})$ and 3 (33 mg). Fraction B (1.5 g) was chromatographed on sephadex LH-20 column and $\mathrm{MeOH}$ (90\%) to yield pure compounds 4 (27 mg), 5 (19 $\mathrm{mg})$ and $6(22 \mathrm{mg})$.

\section{Second part: Biological studies}

\section{Chemicals}

Cisplatin (Cis-Diamminedichloroplatinum (II) Pt $\left(\mathrm{NH}_{3}\right)_{2} \mathrm{Cl}_{2}$ was purchased from Alfa Aesar (PRODUCT OF UNITED STATES), CAS: 15663-27-1. EINECS: 239-733-8.

\section{Experimental animals}

Mature male Swiss Albino mice (Mus musculus), weighing about 2025 grams were obtained from the animal house colony of the National Research Centre (Dokki, Cairo, Egypt). The animals were housed in stainless steel wire mesh cages on a bedding of wood chips, kept in an ambient temperature of $25 \pm 3^{\circ} \mathrm{C}$ on a light/dark cycle of $12 / 12 \mathrm{~h}$ and supplied with food and water ad-libitum.

\section{Ethical consideration}

This prospective study was reviewed and approved by the Animal Ethics Committee of the National Research Centre, Cairo, Egypt (approval number: 1.6.2.1.0) and was carried out according to the National Institute of Health Guide (NIH) for the care and use of laboratory animal's guidelines.

\section{Experimental design and doses}

After one week of acclimatization, 70 mice were fasted overnight before treatment and were randomized into 7 equal groups (10 mice/ group) as follows:

I. Control negative, II. Control plant (treated orally for 5 consecutive days with $600 \mathrm{mg} / \mathrm{kg}$ fig), III, IV. Control positive (treated i.p with 10 and $15 \mathrm{mg} \mathrm{CP}$, a single dose treatment for $24 \mathrm{~h}$ ), VI-VII. Fig + cisplatin: Three groups treated with Ficus carica (200, 400 and $600 \mathrm{mg} / \mathrm{kg}$, orally, 5 consecutive days) + Cisplatin (injected once at the last day of treatment $24 \mathrm{~h}$ after sacrificing)

In all experiments animals were anesthetized using diethyl ether and then killed by cervical dislocation $24 \mathrm{~h}$ after the last treatment. Mice in each group were subdivided into two sub-groups ( 5 animals/each), one for micronucleus and histopathological studies (without colchicine). The second subgroup was injected i.p with colchicine $(40 \mathrm{mg} / \mathrm{kg}) 2.5$ $\mathrm{h}$ before sacrificing and was subjected to chromosomal aberration analysis. Cisplatin and Ficus carica extract were carefully dissolved in distilled water.

\section{Experimental Procedures}

\section{Genotoxic study}

\section{Micronucleus test}

The micronucleus preparation from bone marrow of treated mice was performed following the standard test protocol and according to 
the Guideline (OECD) 474 for Testing of Chemicals ${ }^{14}$. Both femurs were removed and bone marrow flushed with Fetal Bovine Serum (FBS) about $3 \mathrm{~mL}$. Cells were centrifuged at $2000 \mathrm{rpm}$ for $5 \mathrm{~min}$ and smeared on slides. The air-dried slides were fixed by submerging in absolute methanol (for $10 \sim 20 \mathrm{~min}$ ). Fixed slides were stained with May-Grunwald and Giemsa stains. Micronuclei were identified as dark blue staining bodies in the cytoplasm of polychromatic erythrocytes (PE's). The ratio of erythrocytes to nucleated cells was determined and expressed as the percentage of PE's/100 nucleated cells (PE's + NE's). 2000 nucleated cells were counted per each animal (5 animals/group). The cells were scored under a light microscope at a $1000 \times$ magnification.

\section{Chromosomal aberration assay in bone marrow and mouse spermatocytes}

Bone marrow chromosomes were prepared according to the technique described by Fahmy et al. ${ }^{1}$ In brief, mouse bone- marrow cells were collected from both femurs, cells were incubated in hypotonic solution (KCL $0.075 \mathrm{M}$ ) for $20 \mathrm{~min}$ at $37^{\circ} \mathrm{C}$, and then centrifuged. The cell pellets were suspended in a fixative (methanol/glacial acetic acid 3:1). This step was repeated at least twice, then the cells suspended in a few drops of fixative and spread onto frozen slides, air dried, stained with $10 \%$ Giemsa for $30 \mathrm{~min}$, washed, and air dried again.

Spermatocyte chromosomes were prepared from the testes of the same animals according to the protocol described by Hassan et al. ${ }^{15}$. Briefly, the testis was removed and squashed into a petri dish containing an isotonic solution $2.2 \%$ trisodium citrate. Then the cell suspension was centrifuged for 5 minutes at $1500 \mathrm{rpm}$. The cell pellet was incubated in a hypotonic solution $1.1 \%$ trisodium citrate for 20 minutes at $37 \mathrm{C}^{\circ}$ followed by centrifugation. The cell pellet was washed twice by a freshly prepared fixative. A few drops of the fixative cell suspension were dropped in a clean microscopic slide, air dried and stained with $10 \%$ Giemsa stain.

In each a hundred well spread metaphases were analyzed per mouse describing different kinds of abnormalities. Scoring was performed under $2500 \times$ magnification with a light microscope.

Quantitative Real Time-PCR (qRT-PCR) for analysis of hepatic nuclear factor-kappa B (NF-kB), inducible nitric oxide synthase (iNOS) mRNA expression:

Total RNA was isolated from $500 \mu \mathrm{l}$ of liver samples of mice by the standard TRIzol extraction method (Invitrogen, Paisley, UK). To remove any possible genomic DNA contamination, the total RNA samples were pre-treated using DNA-free ${ }^{\mathrm{mt}}$ DNase treatment and removal of reagents kit (Ambion, Austin, TX, USA) following the manufacturer's protocol and were recovered in $100 \mu \mathrm{l}$ molecular biology grade water and stored at $-20^{\circ} \mathrm{C}$. The RNA concentration and purity were determined by Nanodrop Spectrophotometer absorption (Thermo Scientific, USA) at $260 \mathrm{~nm}^{16}$.

Complementary DNA (cDNA) was generated using Superscript Choice Systems (Life Technologies, Breda, Netherlands) according to the manufacturer's instructions. To assess the mRNA expression of NF-kB, iNOS, quantitative real-time PCR was performed using SYBR green PCR Master Mix (Applied Biosystems, CA, USA) as described by the manufacturer. Briefly, in a $25 \mu \mathrm{l}$ reaction volume, $5 \mu \mathrm{l}$ of cDNA were added to $12.5 \mu \mathrm{l}$ of $2 \times$ SYBR green Master Mix and $200 \mathrm{ng}$ of each primer. The sequences of primers are described in Table 1. The temperature profile was as follows: $94{ }^{\circ} \mathrm{C}$ for $3 \mathrm{~min}, 94{ }^{\circ} \mathrm{C}$ for $20 \mathrm{~s}, 60{ }^{\circ} \mathrm{C}$ for $20 \mathrm{~s}$ and $72{ }^{\circ} \mathrm{C}$ for $20 \mathrm{~s}$ for 35 cycles. Changes in the expression of each target gene were normalized relative to the mean critical threshold (CT) values of (GAPDH) as housekeeping gene by the $\Delta \Delta \mathrm{Ct}$ method $^{17}$.

\section{Histopathological studies}

Specimens of testes were dissected and fixed in $10 \%$ buffered formalinsaline for 72 hours, washed in tap water for half an hour, dehydrated in ascending grades of alcohol, cleared in xylene, impregnated in soft paraffin wax at $55^{\circ} \mathrm{C}$ and embedded in hard paraffin. Serial sections of $5-6 \mu \mathrm{m}$ thick will be cut and stained with H\&E stain and analyzed by a light microscope at $400 \times$ magnification $^{18}$. Images will be captured and processed using Adobe Photoshop Version 8.

\section{Immunohistochemical assessment of TNF-a expression}

Preparation was carried according to the technique described by Jammal et al. ${ }^{19}$. Immuno-histochemical staining of tumor necrosis factor-alpha (TNF- $\alpha$ ) antibody was performed with sections of $4 \mu \mathrm{m}$ thick that were deparaffinized and incubated with fresh $0.3 \%$ hydrogen peroxide in methanol for $30 \mathrm{~min}$ at room temperature. Deparaffinized testis slides were incubated with the antibodies against caspase-3 diluted 1:100, and positive cells were determined with streptavidin-biotin-peroxidase secondary antibody (DAKO Universal). The binding sites of antibody were visualized with $\mathrm{DAB}$. The sections were then counterstained with hematoxylin, dehydrated using graded alcohols and xylene, and mounted. The immunostaining intensity and cellular localization of TNF- $\alpha$ were analyzed by light microscope.

\section{Statistical analysis}

Data were computerized and analyzed using Statistical Package of Social Science (SPSS Inc., version 20, Armonk, New York: IBM Corp). One way analysis of variance (ANOVA) followed by Duncan's multiple comparison test was used to determine the difference among the means. The level of statistical significance was set at $\mathrm{P}<0.05$.

\section{RESULTS}

\section{First part: phytochemical studies}

Total phenolic and flavonoid contents of Ficus carica

The phenolic content of Ficus carica was determined in $\mathrm{MeOH}$ extract using Folin- Ciocalteu reagent. While, the total flavonoid content was determined using $\mathrm{AlCl}_{3}$ reagent. The results showed that the $\mathrm{MeOH}$ extract of this plant contains a high content of total phenolics which reached $63.37 \mathrm{mg} / \mathrm{g}$ extract and total flavonoids $(59.67 \mathrm{mg} / \mathrm{g}$ extract). The total phenolic and total flavanoid contents in methanol extract were expressed as chemical equivalents of chlorogenic acid and rutin, respectively.

Table 1: represents the sequence of forward and reverse primers.

\begin{tabular}{cclc}
\hline Gene & & \multicolumn{1}{c}{ Primer sequence $\left(5^{\prime}-\mathbf{3}^{\prime}\right)$} & Primer size (bp) \\
\hline NFk-B & F & CATGAAGAGAAGACACTGACCATGGAAA & 329 \\
& R & TGGATAGAGGCTAAGTGT AGACACG & \\
iNOS & F & TGTGTCAGCCCTCAGAGTAC & 312 \\
& R & CACTGACACTYCGCACAA & 188 \\
GAPDH & F & cggctactagcggtttta cg & \\
& R & aagaagatgcggctg act gt & \\
\hline
\end{tabular}


Identification of isolated phenolic compounds:

\section{> Compound 1 (Chlorogenic acid):}

This compound showed chromatographic properties and color reactions similar to those reported for "chlorogenic acid (blue spot on PC under UV light, turning bright yellow when fumed with ammonia vapor, changing to yellow with $\mathrm{AlCl}_{3}$ spray reagent [26]. Mass spectrum showed a molecular ion $(\mathrm{M}+)$ at $\mathrm{m} / \mathrm{z} 354$, which corresponds to the molecular formula $\mathrm{C}_{16} \mathrm{H}_{17} \mathrm{O}_{9}$. The ${ }^{1} \mathrm{HNMR}$ spectrum $(400 \mathrm{MHz}$, DMSO- $d_{6}$ ) showed signals, 6.34 (H-8', d, J=16.0), $6.84\left(\mathrm{H}-5^{\prime}, \mathrm{d}, \mathrm{J}=8.4\right)$, $7.03\left(\mathrm{H}^{-6}{ }^{\prime}, \mathrm{dd}, \mathrm{J}=8.5,1.8\right), 7.13\left(\mathrm{H}-2^{\prime}, \mathrm{d}, \mathrm{J}=1.8\right), 7.58\left(\mathrm{H}^{-} 7^{\prime}, \mathrm{d}, \mathrm{J}=16.0\right)$. From the above chromatographic and spectroscopic data, compound 1 could be identified as chlorogenic acid"20.

\section{> Compound 2 (Catechin):}

${ }^{1} \mathrm{H}$ NMR (400 MHz, DMSO- $\left.d_{6}\right): \delta$ “6.84 ( $1 \mathrm{H}, \mathrm{d}, J=2.0 \mathrm{~Hz}, \mathrm{H}-2$ '), 6.77 $\left(1 \mathrm{H}, \mathrm{dd}, J=8.1 \mathrm{~Hz}, \mathrm{H}-5^{\prime}\right), 6.71\left(1 \mathrm{H}, \mathrm{dd}, J=2.0,8.1 \mathrm{~Hz}, \mathrm{H}-6^{\prime}\right), 5.92$ $(1 \mathrm{H}, \mathrm{d}, J=2.4 \mathrm{~Hz}, \mathrm{H}-8), 5.85(1 \mathrm{H}, \mathrm{d}, J=2.4 \mathrm{~Hz}, \mathrm{H}-6), 4.56(1 \mathrm{H}, \mathrm{d}, J=$ $8.0 \mathrm{~Hz}, \mathrm{H}-2), 3.97(1 \mathrm{H}, \mathrm{ddd}, J=8.0,8.0,4.8 \mathrm{~Hz}, \mathrm{H}-3), 2.85(1 \mathrm{H}, \mathrm{dd}, J=$ $4.8,16.0 \mathrm{~Hz}, \mathrm{H}-4), 2.50(1 \mathrm{H}, \mathrm{dd}, J=8.0,16.0 \mathrm{~Hz}, \mathrm{H}-4){ }^{\prime \prime} .{ }^{13} \mathrm{C}$ NMR $(100$ $\left.\mathrm{MHz}, \mathrm{DMSO}-d_{6}\right): \delta$ “27.7 (C-4), 66.3 (C-3), 80.9 (C-2), 93.9 (C-6), 95.1 (C-8), 114.5 (C-2'), $115.1\left(\mathrm{C}-5^{\prime}\right), 18.4\left(\mathrm{C}^{\prime} 6^{\prime}\right)$ and other aromatic carbons showed peaks at $\delta$ of 99.1, 130.6, 144.6, 144.8, 155.3, 156.1 and $156.4 " 21$.

\section{> Compound 3 (Quercetin):}

${ }^{1} \mathrm{H}$ NMR (400 MHz, DMSO- $\left.d_{6}\right): \delta$ “7.74 ( $1 \mathrm{H}, \mathrm{d}, J=2.1 \mathrm{~Hz}, \mathrm{H}-2$ '), 7.62 $\left(1 \mathrm{H}, \mathrm{dd}, J=8.3,2.1 \mathrm{~Hz}, \mathrm{H}-6^{\prime}\right), 6.88\left(1 \mathrm{H}, \mathrm{d}, J=8.3 \mathrm{~Hz}, \mathrm{H}-5^{\prime}\right), 6.39(1 \mathrm{H}$, d, $J=2.0 \mathrm{~Hz}, \mathrm{H}-8), 6.18(1 \mathrm{H}, \mathrm{d}, J=2.0 \mathrm{~Hz}, \mathrm{H}-6) .{ }^{13} \mathrm{C} \mathrm{NMR}(100 \mathrm{MHz}$, DMSO- $\left.d_{6}\right): \delta$ d 93.2 (C-8), 98.0 (C-6), 102.9 (C-10), 115.0 (C-2'), 115.4 (C-5'), 119.8 (C-6'), 121.8 (C-1'), 135.5 (C-3), 144.9 (C-3'), 146.7 (C-2), 147.5 (C-4'), 156.0 (C-9), 160.6 (C-5), 163.8 (C-7), 175.7 (C-4)"22.

\section{> Compound 4 (Quercetin-3-O- $\beta$-D-glucopyranoside):}

${ }^{1} \mathrm{H}$ NMR (400 MHz, DMSO- $\left.d_{6}\right): \delta$ “7.70 ( $1 \mathrm{H}, \mathrm{d}, J=1.9 \mathrm{~Hz}, \mathrm{H}-2$ '), 7.68 $\left(1 \mathrm{H}, \mathrm{dd}, J=8.5,1.9 \mathrm{~Hz}, \mathrm{H}-6^{\prime}\right), 6.86\left(1 \mathrm{H}, \mathrm{d}, J=8.5 \mathrm{~Hz}, \mathrm{H}-5^{\prime}\right), 6.36(1 \mathrm{H}$, d, $J=2.2 \mathrm{~Hz}, \mathrm{H}-8), 6.17(1 \mathrm{H}, \mathrm{d}, J=2.2 \mathrm{~Hz}, \mathrm{H}-6), 5.32(1 \mathrm{H}, \mathrm{d}, \mathrm{J}=7.3 \mathrm{~Hz}$, $\mathrm{H}-1$ "), 3.85-3.30 (6H, sugar protons). ${ }^{13} \mathrm{C}$ NMR (100 MHz, DMSO- $\left.d_{6}\right)$ : $\delta 156.2(\mathrm{C}-2), 133.3$ (C-3), 177.5 (C-4), 161.2 (C-5), 98.7 (C-6), 164.1 (C-7), 93.5 (C-8), 156.3 (C-9), 104.0 (C-10), 121.2 (C-1'), 115.5 (C-2'), 144.8 (C-3'), 148.5 (C-4'), 116.2 (C-5'), 121.6 (C-6'), glucose: 100.8 (C1"), 74.1 (C-2"), 76.5 (C-3"), 70.0 (C-4"), 77.6 (C-5”), 61.0 (C-6")"23.

\section{> Compound 5 (Kaempferol-3-O- $\beta-D-$ glucopyranoside):}

${ }^{1} \mathrm{H}$ NMR (400 MHz, DMSO- $d_{6}$ ): $\delta$ “ $8.03(2 \mathrm{H}, \mathrm{d}, J=8.6 \mathrm{~Hz}, \mathrm{H}-2$ ', 6'), $6.87\left(2 \mathrm{H}, \mathrm{d}, J=8.6 \mathrm{~Hz}, \mathrm{H}-3^{\prime}, 5^{\prime}\right), 6.36(1 \mathrm{H}, \mathrm{d}, J=2.3 \mathrm{~Hz}, \mathrm{H}-8), 6.17(1 \mathrm{H}$, d, $J=2.3 \mathrm{~Hz}, \mathrm{H}-6), 5.33\left(1 \mathrm{H}, \mathrm{d}, J=7.6 \mathrm{~Hz}, \mathrm{H}-1\right.$ "). ${ }^{13} \mathrm{C}$ NMR $(100 \mathrm{MHz}$, DMSO- $d_{6}$ ): $\delta 178.1$ (C-4), 164.1 (C-7), 161.2 (C-5),160.2 (C-4'), 157.6 (C-2), 157.2 (C-9), 134.0 (C-3), 130.9 (C-2'), 130.9 (C-6'), 120.9 (C-1'), 114.7 (C-3'), 114.7 (C-5'), 104.2 (C-10), 98.7 (C-6), 93.5 (C-8), 102.7 (C-1"), 74.4 (C-2”), 77.0 (C-3"), 70.0 (C-4"), 76.7 (C-5”), 61.2 (C-6")"24.

\section{, Compound 6 (Luteolin-8-C- $\beta-D-g l u c o p y r a n o s i d e):$}

${ }^{1} \mathrm{H}$ NMR (400 MHz, DMSO-d ) $\delta$ : “13.15 (1H, s, 5-OH), 10.82-9.15 $\left(3 \mathrm{H}, \mathrm{s}, 3^{\prime}, 4^{\prime}, 7^{\prime}-\mathrm{OH}\right), 7.52\left(1 \mathrm{H}, \mathrm{dd}, \mathrm{J}=2.2,8.3 \mathrm{~Hz}, \mathrm{H}-6^{\prime}\right), 7.45(1 \mathrm{H}, \mathrm{d}$, $\left.\mathrm{J}=2.2 \mathrm{~Hz}, \mathrm{H}-2^{\prime}\right), 6.90\left(1 \mathrm{H}, \mathrm{d}, \mathrm{J}=8.3 \mathrm{~Hz}, \mathrm{H}-5^{\prime}\right), 6.65(1 \mathrm{H}, \mathrm{s}, \mathrm{H}-3), 6.56$ $(1 \mathrm{H}, \mathrm{s}, \mathrm{H}-6), 5.05(1 \mathrm{H}, \mathrm{d}, \mathrm{J}=7.0 \mathrm{~Hz}), 3.30-3.90$ (sugar protons, $\mathrm{m}$ ). ${ }^{13} \mathrm{C}$ NMR (100 MHz, DMSO- $d_{6}$ ) $\delta: 164.16$ (C-2), 102.41 (C-3), 182.03 (C-4), 160.47 (C-5), 98.33 (C-6), 162.80 (C-7), 104.65 (C-8), 156.00 (C9), 104.00 (C-10), 121.97 (C-1'), 114.07 (C-2'), 145.95 (C-3'), 149.90 (C-4'), 115.78 (C-5'), $119.45\left(\mathrm{C}-6^{\prime}\right), 73.50\left(\mathrm{C}-1^{\prime \prime}\right), 70.90\left(\mathrm{C}-2^{\prime \prime}\right), 78.88$ $\left(\mathrm{C}-3^{\prime \prime}\right), 70.83\left(\mathrm{C}-4^{\prime \prime}\right), 82.04\left(\mathrm{C}-5^{\prime \prime}\right), 61.76\left(\mathrm{C}-6^{\prime \prime}\right)^{\prime 25}$<smiles>O=C(/C=C/c1ccc(O)c(O)c1)OC1C[C@](O)(C(=O)O)C[C@H](O)[C@H]1O</smiles>

Chlorogenic acid<smiles>O=c1c(O)c(-c2ccc(O)c(O)c2)oc2cc(O)cc(O)c12</smiles><smiles></smiles>

Kaempferol-3-0- $\beta$-D-glucopyranoside

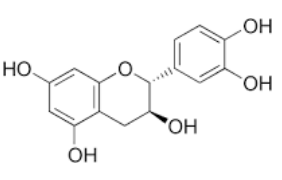

Catechin

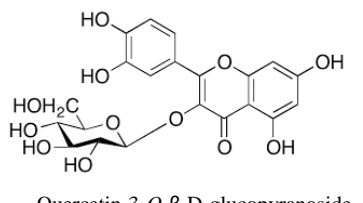

Quercetin-3-O- $\beta$-D-glucopyranoside

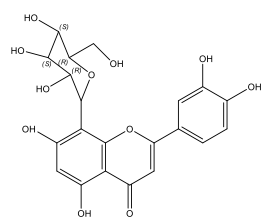

Luteolin-8-C- $\beta$-D-glucopyranoside

\section{Second part: Biological studies}

\section{Cytogenetic studies}

\section{Micronuclei in bone marrow}

The results (Table 2) indicated a significant increase of MPEs after cisplatin treatment where the percentage reached $8.63 \pm 0.21$ after treatment with the dose $15 \mathrm{mg} / \mathrm{kg}$ in comparing with $3.27 \pm 0.40$ for the control. It also induced severe toxicity to bone marrow cells evidenced by an increase in the percentage of PEs/total counted cells. On the other hand Ficus carica alleviated such percentages in a dose-dependent manner. Significant protection was recorded with the highest tested dose.

\section{Chromosomal abnormalities}

Table 3 showed that cisplatin at the tested doses $(10$ and $15 \mathrm{mg} / \mathrm{kg})$ induced highly significant percentage of chromosomal abnormalities in bone marrow cells reached $28.40 \pm 1.2,57.40 \pm 0.68$ respectively compared with $4.4 \pm 0.51$ for control. The results also demonstrated that the combined treatment with Ficus carica extract at different doses ameliorated such effect in a dose-dependent manner. Moreover, Ficus carica alone $(600 \mathrm{mg} / \mathrm{kg})$ had a normal effect as compared with that of the control negative. The majority of aberrations are fragments and/ or breaks and metaphases contained more than five aberrations in the same metaphase (MA). Fragmentation may be included in the whole set of chromosomes. Metaphases with multiple aberrations represent a pronounced percentage (approximately 32\% of the total aberrant metaphases).

In mouse spermatocytes, Table 4 showed that both doses of cisplatin and also Ficus carica at the dose $600 \mathrm{mg} / \mathrm{kg}$ had no significant effect on chromosomal abnormalities and their effect is nearly the same as control negative.

\section{Quantitative gene expression}

Table 5 \& Figure 1 demonstrated that cisplatin induced a significant increase in the expression of iNOS gene compared to negative control $(\mathrm{P}<0.001)$. Ficus carica had normal effect on iNOS gene the same as control negative $(\mathrm{P}=0.189)$. The results also demonstrated that Ficus carica at different doses (in combined treatment fig + cisplatin) alleviated the over expression of iNOS gene compared to cisplatin group especially with the doses 400 and $600 \mathrm{mg} / \mathrm{kg}(\mathrm{P}<0.001)$. No 
Table 2: Frequency of polychromatic erythrocytes (PEs) and PEs with micronuclei induced in mouse bone-marrow cells after treatment with cisplatin and Ficus carica extract.

\begin{tabular}{|c|c|c|c|c|}
\hline \multirow{2}{*}{ Treatment and doses $(\mathrm{mg} / \mathrm{kg})$} & \multirow{2}{*}{$\begin{array}{l}\text { PEs } \\
\text { NO. }\end{array}$} & \multicolumn{3}{|c|}{ MPEs } \\
\hline & & Mean \pm S.E & NO. & Mean \pm S.E \\
\hline I. Control (non-treated) & 550 & $5.50 \pm 0.19^{a}$ & 18 & $3.27 \pm 0.40^{\mathrm{a}}$ \\
\hline II. Control (plant, 600mg/kg) & 512 & $5.12 \pm 0.14^{\mathrm{a}}$ & 17 & $3.32 \pm 0.41^{\mathrm{a}}$ \\
\hline \multicolumn{5}{|l|}{ III, IV. Cisplatin } \\
\hline $10 \mathrm{mg} / \mathrm{kg}$ & 936 & $9.36 \pm 0.40^{b}$ & 64 & $6.84 \pm 0.47^{b}$ \\
\hline $15 \mathrm{mg} / \mathrm{kg}$ & 1622 & $16.22 \pm 0.29^{c}$ & 140 & $8.63 \pm 0.21^{c}$ \\
\hline \multicolumn{5}{|l|}{ V-VII. cisplatin + Ficuscarica } \\
\hline Cisplatin $+200 \mathrm{mg} / \mathrm{kg}$ & 1436 & $14.36 \pm 1.37^{c}$ & 94 & $6.54 \pm 0.50^{b}$ \\
\hline Cisplatin $+400 \mathrm{mg} / \mathrm{kg}$ & 1004 & $10.04 \pm 0.65^{\mathrm{b}}$ & 68 & $6.77 \pm 0.74^{b}$ \\
\hline Cisplatin $+600 \mathrm{mg} / \mathrm{kg}$ & 866 & $8.66 \pm 0.68^{b}$ & 45 & $5.19 \pm 0.96^{b}$ \\
\hline
\end{tabular}

Number of examined nucleated cells $=2000$ /mouse ( 5 mice / group). The values having different superscript letters in each column are significantly different from one another as calculated by ANOVA. The data were presented as mean \pm S.E. $(n=5)$.

Table 3: Frequency of chromosomal aberrations induced in bone marrow cells after treatment with cisplatin and Ficus carica extract.

\begin{tabular}{|c|c|c|c|c|c|c|c|}
\hline \multirow[b]{2}{*}{ Treatment and doses } & \multicolumn{2}{|c|}{ Abnormal metaphases } & \multicolumn{5}{|c|}{ No. of different types of chromosomal aberrations } \\
\hline & NO. & Mean \pm S.E & $\begin{array}{c}\text { Chromat.and/or } \\
\text { chromos. } \\
\text { Gap }\end{array}$ & $\begin{array}{c}\text { Frag. and / or } \\
\text { break }\end{array}$ & $\begin{array}{l}\text { Frag. and or } \\
\text { break +gap }\end{array}$ & MA & $\begin{array}{c}\text { RT/or Ring } \\
\text { chromosome }\end{array}$ \\
\hline I. Control(non-treated) & 22 & $4.4 \pm 0.51^{\mathrm{a}}$ & & 7 & - & - & - \\
\hline II. Control plant $(600 \mathrm{mg} / \mathrm{kg})$ & 23 & $4.6 \pm 0.68^{a}$ & 11 & 12 & - & - & \\
\hline \multicolumn{8}{|l|}{ III-IV. Cisplatin } \\
\hline $10 \mathrm{mg} / \mathrm{kgb} . w t$ & 142 & $28.40 \pm 1.2^{\mathrm{d}}$ & 16 & 44 & 8 & 74 & - \\
\hline $15 \mathrm{mg} / \mathrm{kgb} . w \mathrm{t}$ & 287 & $57.40 \pm 0.6^{\text {ef }}$ & 12 & 113 & 63 & 91 & 8 \\
\hline \multicolumn{8}{|l|}{ V-VII. Cisplatin+ Ficus carica } \\
\hline$+200 \mathrm{mg} / \mathrm{kg}$ & 216 & $43.2 \pm 1.32^{\mathrm{de}}$ & 33 & 105 & 18 & 60 & - \\
\hline +400 mg/kg & 191 & $38.2 \pm 2.15^{\mathrm{de}}$ & 24 & 108 & 9 & 50 & - \\
\hline$+600 \mathrm{mg} / \mathrm{kg}$ & 134 & $26.8 \pm 1.91^{\mathrm{c}}$ & 16 & 85 & 9 & 24 & - \\
\hline
\end{tabular}

Number of examined metaphases $=500$ (100 metaphases/mouse, 5 mice/group). Chromat. = Chromatid; Frag. $=$ fragment, MA=Multiple aberrations. RT= Robertsonian translocation. The values having different superscript letters in each column are significantly different from one another as calculated by ANOVA. The data were presented as mean $\pm \operatorname{SE}(n=5)$.

Table 4: Frequency of chromosomal abnormalities in primary spermatocytes of male mice induced after treatment with different doses of cisplatin and Ficus carica extract.

\begin{tabular}{|c|c|c|c|c|}
\hline \multirow[t]{2}{*}{ Treatment and doses } & \multicolumn{2}{|c|}{ Abnormal metaphases } & \multicolumn{2}{|c|}{$\begin{array}{l}\text { No. of different types of chromosomal } \\
\text { abnormalities }\end{array}$} \\
\hline & NO. & Mean \pm S.E & $X Y-U$ & A- U \\
\hline I-Control (non-treated) & 19 & $3.8 \pm 0.58^{\mathrm{a}}$ & 12 & 7 \\
\hline II- Control plant $(600 \mathrm{mg} / \mathrm{kg})$ & 16 & $3.2 \pm 0.37^{\mathrm{a}}$ & 10 & 6 \\
\hline \multicolumn{5}{|l|}{ III, IV. Cisplatin } \\
\hline $10 \mathrm{mg} / \mathrm{kg} \mathrm{b.wt}$ & 20 & $4.0 \pm 0.45^{\mathrm{a}}$ & 15 & 5 \\
\hline $15 \mathrm{mg} / \mathrm{kg}$ b.wt & 22 & $4.4 \pm 0.51^{\mathrm{a}}$ & 13 & 9 \\
\hline
\end{tabular}

Number of examined metaphases=500/mouse (5 mice/group); $X Y-U=X Y$-univalent; $A-U=$. Autosomal univalent. 
Table 5: Quantitative iNOS and NF-k $\beta$ gene expressions after treatment with cisplatin and Ficus carica extract.

\begin{tabular}{|c|c|c|c|c|c|c|}
\hline \multirow{2}{*}{ Treatment and doses } & \multicolumn{6}{|c|}{ 95\% Confidence Interval for Mean } \\
\hline & Mean & Std. Deviation & Lower Bound & Upper Bound & Minimum & Maximum \\
\hline \multicolumn{7}{|l|}{ INOS gene } \\
\hline I. Negative Control & 0.76 & 0.05 & 0.637 & 0.89 & 0.72 & 0.82 \\
\hline II. Cisplatin & 2.98 & 0.13 & 2.65 & 3.32 & 2.87 & 3.13 \\
\hline III. Ficus carica & 0.94 & 0.028 & 0.87 & 1.015 & .91 & 0.96 \\
\hline IV. Cisplatin +fig (200 mg) & 2.20 & 0.053 & 2.07 & 2.339 & 2.16 & 2.26 \\
\hline V. Cisplatin + fig(400 mg) & 1.75 & 0.139 & 1.406 & 2.097 & 1.60 & 1.87 \\
\hline VI. Cisplatin + fig (600mg) & 1.69 & 0.034 & 1.61 & 1.78 & 1.66 & 1.73 \\
\hline \multicolumn{7}{|l|}{ NF-k $\beta$ gene } \\
\hline I. Negative Control & 1.20 & 0.056 & 1.065 & 1.34 & 1.14 & 1.25 \\
\hline II.Cisplatin & 4.32 & 0.167 & 3.9 & 4.74 & 4.17 & 4.50 \\
\hline III. Ficus carica & 1.34 & 0.25 & .72 & 1.97 & 1.12 & 1.62 \\
\hline IV. Cisplatin + fig (200mg) & 3.15 & 0.357 & 2.27 & 4.047 & 2.82 & 3.53 \\
\hline V. Cisplatin + fig (400mg) & 2.35 & 0.33 & 1.526 & 3.18 & 1.99 & 2.63 \\
\hline VI. Cisplatin + fig $(600 \mathrm{mg})$ & 1.96 & 0.268 & 1.298 & 2.63 & 1.80 & 2.28 \\
\hline
\end{tabular}

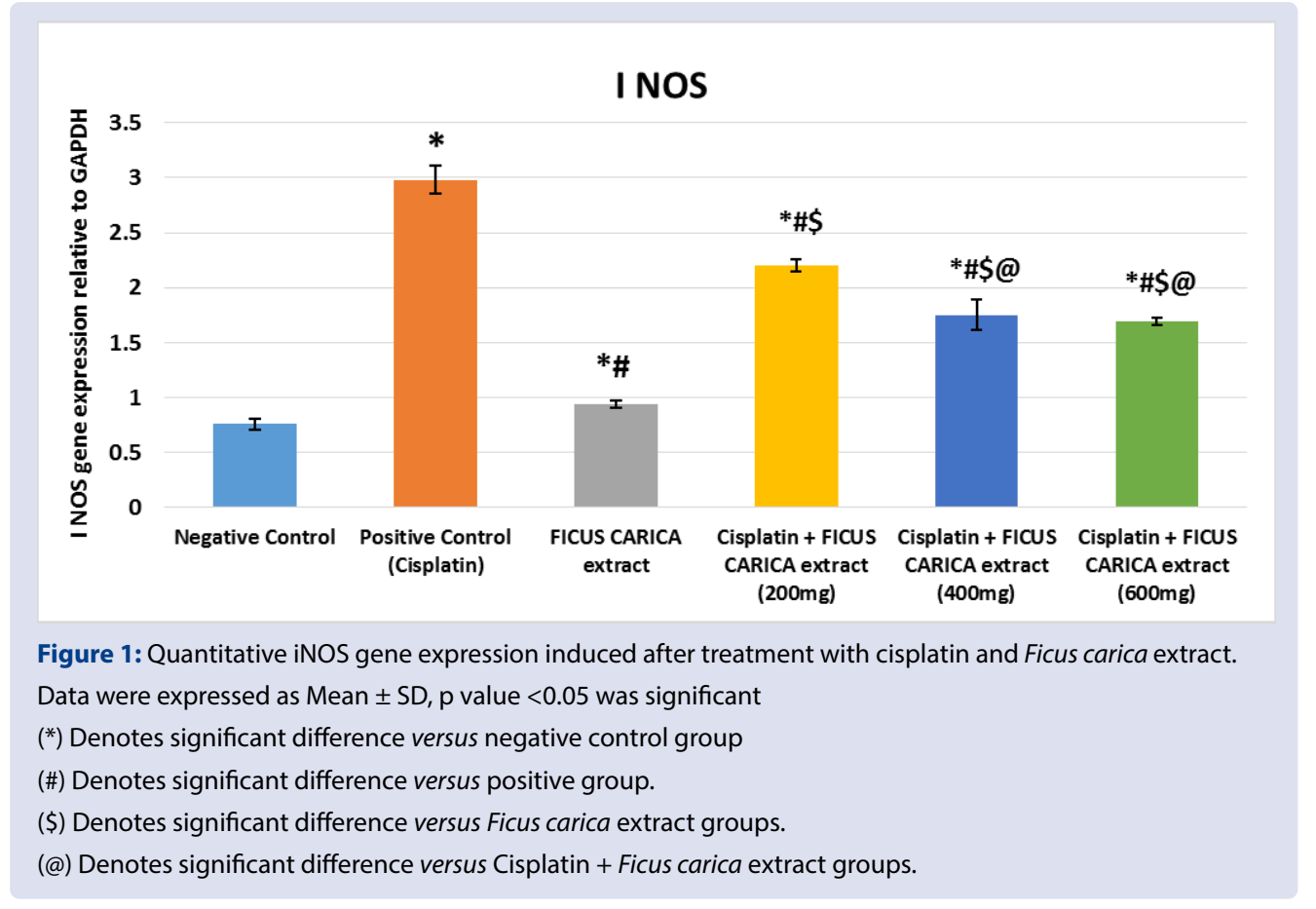

significant difference between the effects of the two doses 400 and 600 $\mathrm{mg} / \mathrm{kg}$ fig $(\mathrm{P}=0.963)$.

Concerning the gene NF-kB the results (Table 5, Figure 2) demonstrated an over expression of the gene after cisplatin treatment $(15 \mathrm{mg} / \mathrm{kg})$ compared to the negative control $(\mathrm{P}<0.001)$ and that there was no significant difference between Ficus carica (plant control) and the negative control $(\mathrm{P}=0.963)$. The results also demonstrated the protective role of fig. When fig was given with cisplatin the expression of NF-kB gene decreased to a good extent especially with the doses 400 and 600 $\mathrm{mg} / \mathrm{kg}$ in comparison with cisplatin alone $(\mathrm{P}<0.001)$ but the expression was still elevated in comparison with the control negative $(\mathrm{P}<0.001$, $0.002,0.034)$ after the three tested doses of fig respectively.

\section{Histopathological studies}

The histological observations of the testis from control and Ficus carica groups showed normal appearance of spermatogenic and interstitial cells and seminiferous tubules (Figure 3A). Mice treated with $\mathrm{CP}$ showed many histopathological alterations in spermatogenic cells, pyknotic nuclei appearance, dilatation and congestion of blood vessels with marked reduction of spermatozoa in the lumen of the seminiferous tubules (Figure 3B). In combination with cisplatin and fig, it can be detected that the lower and the medium dose of the plant gave a partial improvement of spermatogenic cells. Pyknotic nuclei and many alterations of the spermatogenic process were still observed (Figure 3C). With the highest tested dose of fig, all histopathological changes were reduced and spermatogenic cells were improved to a good extent while the interstitial congestion was still found (Figure 3D). Immunohistochemistry of TNF- $\alpha$ :

Undetectable immunoreactivity of TNF- $\alpha$ in control or plant treated mice was observed (Figure 4A). In the cisplatin group, intense of TNF- $\alpha$ expression was detected mainly in seminiferous tubules of the testis (Figure $4 \mathrm{~B}$ ). Mice treated with cisplatin and plant at the three tested doses showed moderate to weak TNF- $\alpha$ immunoreactivity (Figure $4 \mathrm{C}$ \& D). Dose -dependent protection was recorded. 

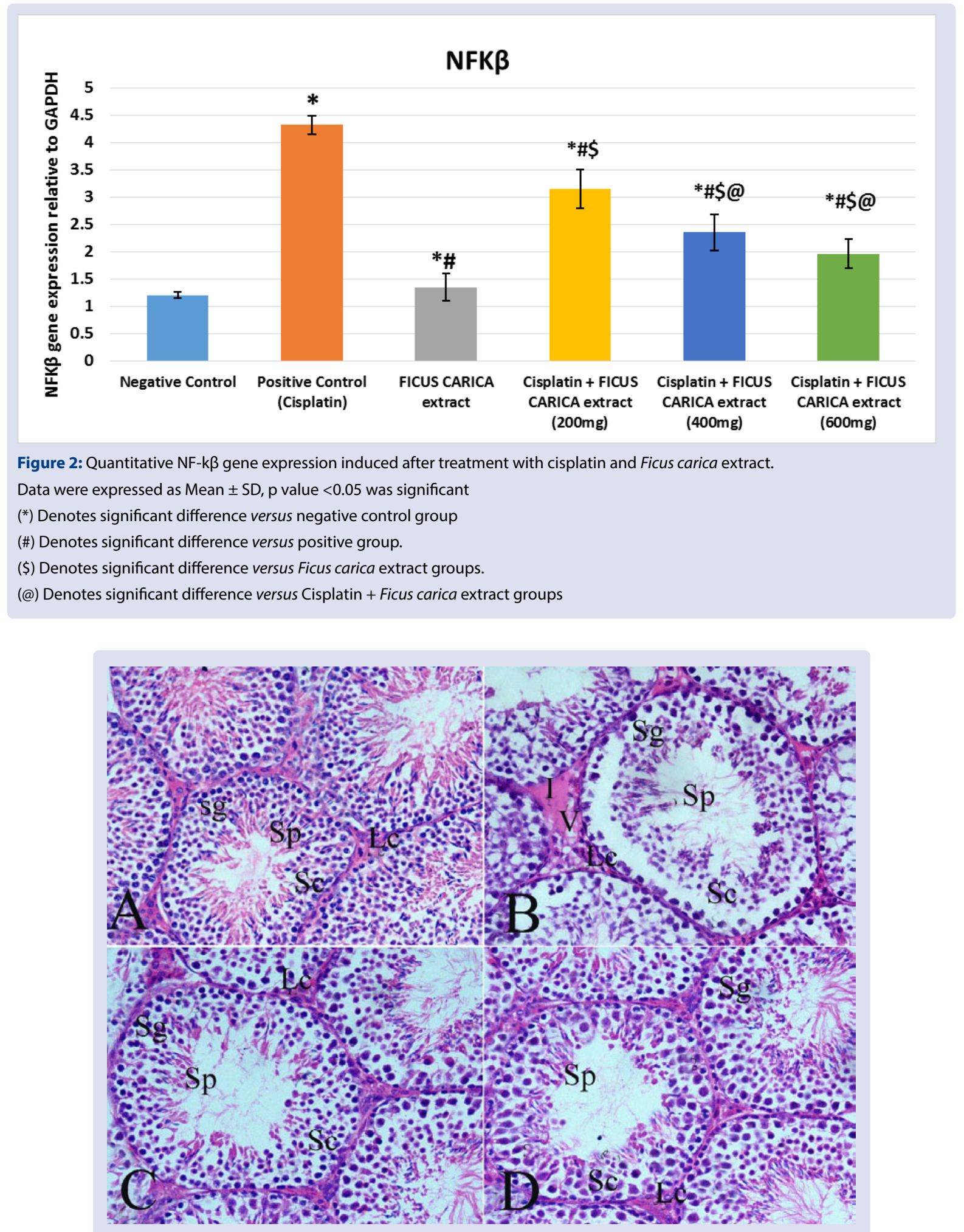

Figure 3: Light micrographs of sections of mice testis induced after treatment with cisplatin and Ficus carica. A. Control group showing normal seminiferous tubules, including spermatogonia (Sg), spermatocytes (Sc) and spermatids (Sp) Leydig cells (LC).

B. Cisplatin group showing marked reductions of $(\mathrm{Sg}),(\mathrm{Sc})$, spermatozoa produced in the lumen of the seminiferous (Sp), vacuolated (V) pyknotic (LC), interstitial congestion (I).

C. Cisplatin and the medium dose of plant showing mild reductions of $(\mathrm{Sg}),(\mathrm{Sc})$, and spermatozoa produced in the lumen of the seminiferous (Sp), with pyknotic (LC).

D. Cisplatin and the high dose of plant showing restored alteration of $(\mathrm{Sg}),(\mathrm{SC})$ and spermatozoa produced in the lumen of the seminiferous (Sp), with pyknotic (LC) (H\& E staining- $\times 400$ magnification). 


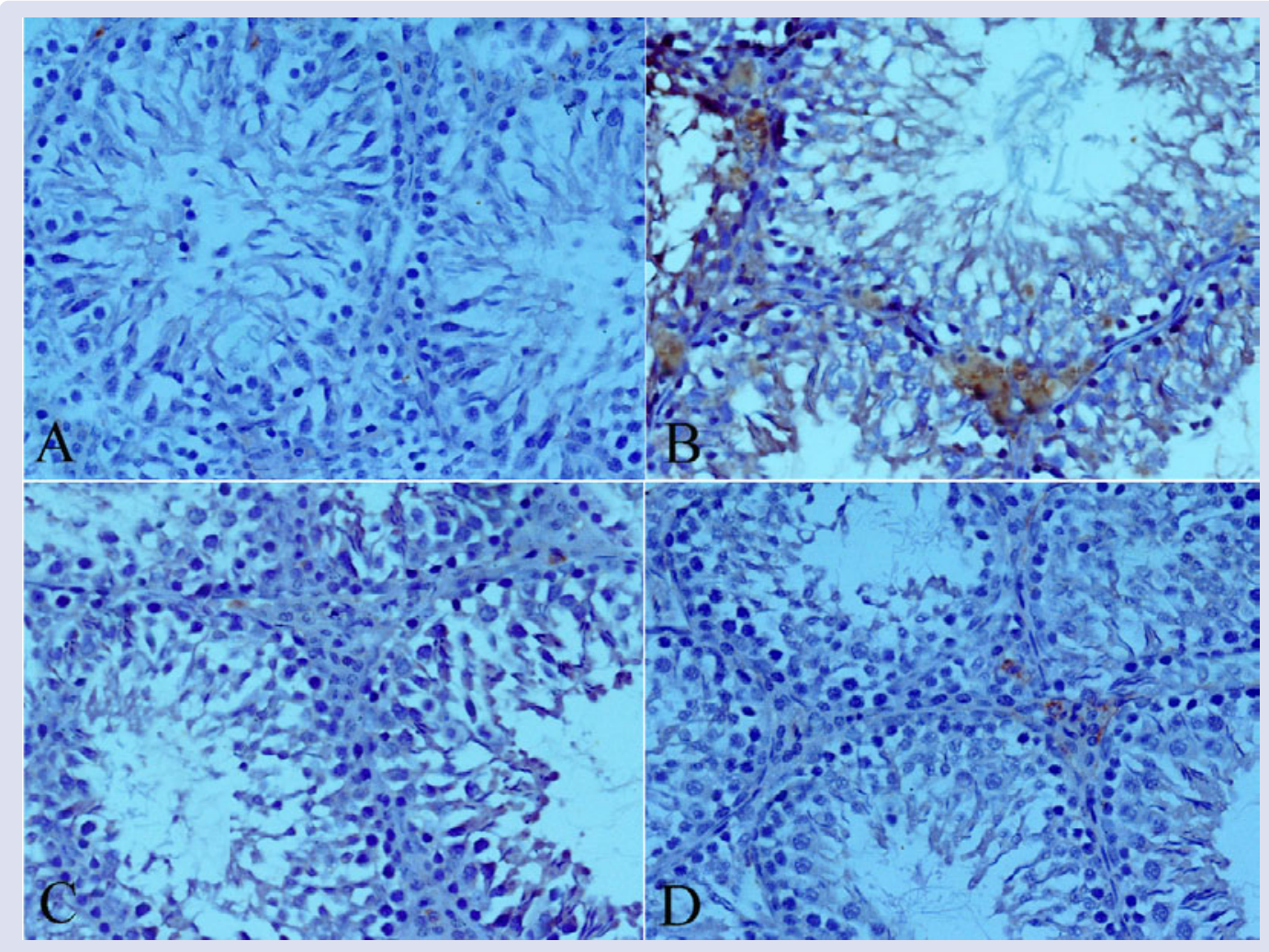

Figure 4: Immunohistochemical expression of TNF-a induced after treatment with cisplatin and Ficus carica

A Negative control group showing undetectable immunoreactivity

B. Cisplatin group showing intense immunoreactivity

C. Cisplatin + the medium dose of plant showing mild immunoreactivity

D. Cisplatin + the high dose of plant showing weak immunoreactivity (TNF-a immune staining- $\times 400$ ).

\section{DISCUSSION}

Cisplatin $(\mathrm{CP})$ is a platinum-based standard antineoplastic drug that is used against different types of solid tumors and neoplasms. Like other chemotherapeutic drugs $\mathrm{CP}$ possesses many side effects in clinical uses and experimental animal studies. The use of $\mathrm{CP}$ for clinical purposes is limited by its side effects ${ }^{12}$.

Plants have been an important part of sophisticated traditional medicine for thousands of years. Nowadays, scientific researches have shown that many plants can induce anti-mutagenic, chemoprotective, anti-inflammatory and antioxidant activities ${ }^{1}$. In the present study, the protective efficacy of Ficus carica leaves methanol extract was investigated against genotoxicity, liver gene expression and reproductive toxicity of cisplatin. Separation and identification of some active constituents of fig and their biological bioactivity were discussed.

The genetic endpoint was discussed in the present work by detecting micronuclei in polychromatic erythrocytes (MPEs) of bone marrow, chromosomal aberrations (CAs) in bone marrow and primary spermatocytes and also its effect on the expression of the liver genes TNF- $\alpha$, iNOS and NF-kB was demonstrated. The detection of MPEs is one of the most commonly used endpoints in the field of genetic toxicology ${ }^{14}$. The results demonstrated that cisplatin induced significant percentage of MPEs which increased by dose. Also it induced highly significant incidence of chromosomal aberrations in bone marrow cells especially with the highest tested dose. Generally, it was accepted that MPEs are formed as a consequence of chromosome breakage/fragment or aneuploidy. Moreover, micronucleus assay is considered as a sensitive method for determining DNA damage induced after chemotherapy or radiotherapy ${ }^{26}$. The present results also showed that cisplatin induced cytotoxicity to bone marrow cells by increasing the percentage of PEs in relation to normochromatic erythrocytes. The present results coincide with the findings of other authors who demonstrated that cisplatin induced myelosuppression in bone marrow cells and induced different forms of genotoxicity e.g micronuclei, chromosomal aberrations in mouse bone marrow and DNA damage ${ }^{10,27}$. In the present work Ficus carica extract administrated to cisplatin-treated mice reversed part of these alterations in a dose-dependent manner. Anti-mutagenic effect of Ficus carica extract was previously demonstrated against mutations induced by N-metil-N'-nitro-N-nitrozoguanidin (MNNG) in Vicia faba cells, chlorophyll mutations in Arabidopsis thaliana and $\mathrm{NaF}$ induced mutability in rat marrow cells ${ }^{28}$. It was also reported to have the ability to decrease the frequency of spontaneous and induced- $\gamma$ ray chromosome abnormalities in meristematic cells of Vicia faba and bone marrow cells of mice ${ }^{29}$.

On the contrary, cisplatin did not induce any significant effect on chromosomal aberrations in mouse primary spermatocytes (germ cells) after treatment at the two dose levels examined in comparing to the control. It was previously reported that chromosome damage in germ cells is an indirect method to assess transmissible genetic damage ${ }^{15}$. The results obtained gave cisplatin an advantage over some other chemotherapeutic drugs which induce high percentage of chromosome defects in germ cells eg: 5 -florouracil ${ }^{30}$; Etoposide $^{31}$; methotrexate and tamoxfine ${ }^{32}$; vinblastine ${ }^{33}$ and cyclophosphamide ${ }^{34}$.

Histopathological investigation of the testes revealed many deleterious effects after cisplatin treatment that produced a pronounced alteration of spermatogenesis with marked reduction of spermatozoa in the lumen 
of seminiferous tubules. These histopathological changes were reversed with dose-dependent manner in mice treated with Ficus carica extract. The mentioned results coincide well with the findings of other authors who demonstrated that cisplatin had impaired spermatogenesis and resulted in gonadal dysfunction, altered Leydig cells and antioxidant enzyme status ${ }^{12}$. Also temporary or permanent azoospermia are other forms of side effects associated with cisplatin treatment. Such side effects are attributed to oxidative and nitrosative damage generated by $\mathrm{CP}^{35}$. All of these defects are associated with impairment in reproductive function after $\mathrm{CP}$ treatment.

Concerning to the effect of cisplatin on the gene level. The results obtained from using QRT-PCR indicated an overexpression of the two genes NF-kB and iNOS after treatment with cisplatin $(15 \mathrm{mg} /$ $\mathrm{kg}$ ). It is well documented that the nuclear factor- $\kappa \mathrm{B}(\mathrm{NF}-\kappa \mathrm{B})$ family of transcription factors controls the expression of genes involved in many critical physiological responses such as inflammatory responses, differentiation, proliferation, cell adhesion and apoptosis ${ }^{36}$. Constitutively activated NF- $\kappa B$ transcription factors have been associated with several aspects of tumorigenesis, including promoting cancer-cell proliferation, preventing apoptosis, and increasing tumor's angiogenic and metastatic potential. Activation of the NF- $\kappa B$ plays a role in inflammation through the induction of transcription of several pro-inflammatory genes ${ }^{37}$. Oxidative stress plays a critical role in NF$\mathrm{kB}$ activation by diverse agents. This hypothesis is based on that oxidant such as $\mathrm{H}_{2} \mathrm{O}_{2}$ can activate $\mathrm{NF}-\mathrm{kB}^{38}$ and that drugs with antioxidant properties have an inhibitory effect on the gen $\mathrm{e}^{39}$. The results of the present work demonstrated that Ficus carica in the combined-treated groups alleviated the overexpression of the NF-kB gene.

Inducible nitric oxide synthase (iNOS) gene is located on chromosome 17 and has been implicated in a wide variety of diseases. This gene encodes a nitric oxide synthase (NOS) which is expressed in liver and induced by a combination of lipopolysaccharide and certain cytokines. The nitric oxide synthase enzyme forms nitric oxide that besides being a signaling molecule plays an important role in host immune response. Nitric oxide is a reactive free radical which acts as a mediator in many biological reactions including neuro-transmission, antimicrobial and antitumor activities ${ }^{40}$. Increased levels of NO have cytotoxic and DNAdamaging effects. In inflammatory states, nitric oxide may be synthesized from precursor L-arginine via inducible NO synthase (iNOS) in large amounts for prolonged periods of time. When $\mathrm{NO}$ acts as an effector molecule under these conditions, it may be toxic to cells by inhibition of iron-containing enzymes or initiation of DNA single-strand breaks ${ }^{41}$ .The results showed that Ficus carica at the highest tested dose reversed the over expression of iNOS gene to near the normal value. TNF- $\alpha$ gene is critical in the regulation of invasion, angiogenesis, and tumor metastasis. Immunohistochemically investigation in the tissues is a surrogate of mutational analysis. In the present study, intense of TNF- $\alpha$ expression was detected mainly in seminiferous tubules of the testis after CP treatment. Ficus carica at different doses relieve this effect.

On referring to the mechanism of action of cisplatin and Ficus carica, it is generally known that CP is an alkylating agent that kills cells by several mechanisms including DNA damage in the form of single and double-strand breaks that are poorly repaired by nuclear repair enzymes 9 , production of reactive oxygen species (ROS) which inhibit the antioxidant defense systems and the induction of apoptosis ${ }^{12}$. As with all chemotherapeutic drugs, CP kills both cancerous and normal cells. Therefore, it comes with severe side effects such as nephrotoxicity, infertility, neurotoxicity, and ototoxicity ${ }^{9}$. Genotoxicity induced by some anticancer drugs in normal tissues might also result in secondary malignancies in patients especially after extended remission ${ }^{1}$.

Ficus carica (Moraceae genus) is an important genetic resource due to its high nutritional and economic values. Fig leaves are known to be rich in flavonoids ${ }^{42}$. This opinion is supported by the results obtained in the present work where the total flavonoid content reached $59.67 \mathrm{mg} / \mathrm{g}$ extract. Flavonoids are potent antioxidants that inhibit lipid peroxidation ${ }^{43}$, protect the tissues from free radicals by direct scavenging ROS, reactive nitrogen species (RNS), and activating antioxidant enzymes ${ }^{1}$. Fig is also an excellent source of phenolic compounds (represents $63.37 \mathrm{mg} / \mathrm{kg}$ extract in the present results), whereas red wine and tea, which are two good sources of phenolic compounds, contain phenols lower than those in fig ${ }^{44}$. Arvaniti et $a l .{ }^{45}$ reported that antioxidant capacity of figs is highly correlated with their amount of phenolic compounds. Phenolic compounds can act as antioxidants by different ways: reducing agents, hydrogen donators, free radical scavengers, singlet oxygen quenchers, and so forth ${ }^{2}$. Indepth chromatographic investigation of the active constituents of Ficus carica extract resulted in the identification of Catechin, Luteolin-8-C$\beta$-D-glucopyranoside, Quercetin, quercetin-3-O- $\beta$-d-glucopyranoside, Chlorogenic acid and Kaempferol-3-O- $\beta$-D-glucopyranoside. Catechins were previously demonstrated to have protection against oxidative DNA damage ${ }^{46}$; chlorogenic acid and quercetin have antioxidant and anti-inflammatory properties ${ }^{47}, 48$. Quercetin-3-O- $\beta$-d-glucopyranoside was reported as a cytoprotective agent by decreasing in the generation of reactive oxygen species ${ }^{49}$; Kaempferol-3-O- $\beta$-D-glucopyranoside recorded scavenging activities in the ONOO and DPPH tests ${ }^{50}$ and Luteolin has antitumor therapeutic effects ${ }^{51}$. Previously some phenolic compounds with reported pharmacological properties have been isolated from fig leaves, namely furanocoumarins like psoralen and bergapten $^{52}$; flavonoids like rutin ${ }^{53}$; phenolic acids like ferrulic acid and also phytosterols like taraxasterol ${ }^{54}$.

In conclusion, this study shows that Ficus carica has important role in mitigating Cisplatin-mediated genotoxicity and reproductive impairments. Ficus carica is rich with many bioactive constituents and may serve as a promising candidate for future development.

\section{FUNDING}

This research work was funded by the in-house project (No.11010345) for the eleventh research plan (2017-2019), National Research Centre, Cairo, Egypt.

\section{REFERENCES}

1. Fahmy M A, Farghaly A A, Hassan E E, Hassan E M, Abdel-Samie N S, bdelGhany E M, Omara E A.. Fennel (Foeniculum vulgare) essential oil ameliorates DNA and histopathological damage induced by cyclophosphamide in mice. Bioscience Research. 2019;16(1):320-36

2. Mawa S, Husain K, Jantan I. Ficus carica L. (Moraceae): Phytochemistry, Traditional Uses and Biological Activities. Evid Based Complement Alternat Med. 2013;974256

3. Patil $V \vee$, Bhangale $S \mathrm{C}$, Patil $\vee \mathrm{R}$. Studies on immunomodulatory activity of Ficus carica. Int J Pharm Pharm Sci. 2010;2(4):97-9.

4. Patil V V, Patil V R. Evaluation of anti-inflammatory activity of Ficus carica Linn leaves. Indian Journal of Natural Product and Resources. 2011;2(2):151-5.

5. Turan A, Celik I. Antioxidant and hepatoprotective properties of dried fig against oxidative stress and hepatotoxicity in rats. Int J Biol Macromol, 2016;91:554-9.

6. Deepa P, Sowndhararajan K, Kim S, Park S J. A role of Ficus species in the management of diabetes mellitus: A review. J Ethnopharmacol, 2018;215:21032.

7. Ghandehari F, Fatemi M. The effect of Ficus carica latex on 7, 12-dimethylbenz (a) anthracene-induced breast cancer in rats. Avicenna J Phytomed, 2018;8(4):28695.

8. Crona DJ, Faso A, Nishijima TF, McGraw K A, Galsky M D, Milowsky M I. A Systematic Review of Strategies to Prevent Cisplatin-Induced Nephrotoxicity. Oncologist 2017;22(5):609-19

9. Fuertes M A, Castilla J, Alonso C, Prez J M. Cisplatin biochemical mechanism of action: From cytotoxicity to induction of cell death through interconnections between apoptotic and necrotic pathways. Curr Med Chem. 2003;10(3):257-66.

10. Basu A, Bhattacharjee A, Samanta A, Bhattacharya S. An oxovanadium (IV) complex protects murine bone marrow cells against cisplatin-induced myelotoxicity and DNA damage. Drug Chem Toxicol. 2017;40(3):359-67. 
11. Quintanilha J C F, de Sousa V M, Visacri M B, Amaral L S, Santos R M M, Zambrano T, Salazar L A, Moriel P. Involvement of cytochrome P450 in cisplatin treatment: implications for toxicity. Cancer Chemother Pharmacol. 2017;80(2):223-33

12. Jahan S, Munawar A, Razak S, Anam S, Ain Q U, Ullah H, Afsar T, Abulmeaty M, Almajwal A. Ameliorative effects of rutin against cisplatin-induced reproductive toxicity in male rats. BMC Urol. 2018;18(1):107.

13. Meda A, Lamien C E, Romito M, Millogo J, Nacoulma O G. Determination of the total phenolic, flavonoid and proline contents in Burkina Fasan honey, as well as their radical scavenging activity. Food Chemistry. 2005;91(3):571-7.

14. OECD Guidelines for the Testing of Chemicals, Genetic Toxicology. 2016. Mammalian Erythrocyte Micronucleus Test, Organisation for Economic Cooperation and Development, Paris, TG 474

15. Hassan N HA., Fahmy M A, Farghaly A A. Hassan E E S. Antimutagenic effects of selenium and vitamins against the genotoxicity induced by cobalt chloride in mice. Cytologia. 2006;71(3): 201-22.

16. Sabry D, Mostafa A, Mekawey D, Altaib Z, Shamaa A, Hany A, et al. An experimental model: intrauterine adhesion versus subendometrial fibrosis. Biomedical Research. 2018;29(17):3311-8.

17. Abdel Azim S A., Darwish H A., Rizk M Z., Ali S A., Kadry M O. Amelioration of titanium dioxide nanoparticles-induced liver injury in mice: Possible role of some antioxidants. Experimental and Toxicologic Pathology. 2015;67:305-14.

18. Drury R., Wallington E. Carleton's histological techniques. $5^{\text {th }}$ Edn, Toronto. Oxford, New York:1980.

19. Jammal M P, DA Silva A A, Filho A M, DE Castro Côbo E, Adad S J, Murta $E$ F Nomelini RS. Immunohistochemical staining of tumor necrosis factor-a and interleukin-10 in benign and malignant ovarian neoplasms. Oncol Lett. 2015;9(2):979-83

20. Wang M, Simon I E, Aviles I F, He K, Zheng Q Y, Tadmor Y. Analysis of antioxidative phenolic compounds in artichoke (Cynara scolymus L.). J Agric Food Chem. 2003;51(3):601-8

21. Kim J H, Byun J C, Bandi A K, Hyun C G, Lee N H. Compounds with elastase inhibition and free radical scavenging activities from Callistemon lanceolatus. Journal of Medicinal Plants Research. 2009;3(11):914-20.

22. Guvenalp Z, Kilic N., Kazaz C., Kaya Y., Demirezer O. Iridoids, flavonoids and monoterpene glycosides from Galium verum subsp. verum. Turk J Chem. 2006;30:515-23.

23. Nawwar M A M, El-Mousallamy A M D, Barakat H H, Buddrus J, Linscheid M. Quercetin 3-glycosides from the leaves of Solanum nigrum. Phytochemistry. 1989;28(6):1755-7.

24. Xu X, Gao X, Jin L, Bhadury P S, Yuan K, Hu D, Song B, Yang S. Antiproliferation and cell apoptosis inducing bioactivities of constituents from Dysosma versipellis in PC3 and Bcap-37 cell lines. Cell Division. 2011;6 (1):14.

25. Zhou X, Peng J, Fan G, Wu Y. Isolation and purification of flavonoid glycosides from Trollius ledebouri using high-speed counter-current chromatography by stepwise increasing the flow-rate of the mobile phase. Journal of Chromatography. 2005;1092(2):216-21

26. Driessens G, Harsan L, Robaye B, Waroquier D, Browaeys P, Giannakopoulos $X$, et al. Micronuclei to detect in vivo chemotherapy damage in a p53 mutated solid tumour. Br J Cancer. 2003;89(4):727-9.

27. Khynriam D, Prasad S B. Cisplatin-induced genotoxic effects and endogenous glutathione levels in mice bearing ascites Dalton's lymphoma. Mutat Res. 2003;526(1-2):9-18

28. Agabeîli R.A, Kasimova T E. Antimutagenic activity of Armoracia rusticana, Zea mays and Ficus carica plant extracts and their mixture. Tsitol Genet. 2005;39(3):75-9.

29. Agaberili R A, Kasimova T E, Alekperov U K. Antimutagenic activity of plant extracts from Armoracia rusticana, Ficus carica and Zea mays and peroxidase in eukaryotic cells. Tsitol Genet. 2004;38(2):40-5.

30. Choudhury R C, Misra S, Jagdale M B. Palo A K. Induction and transmission of cytogenetic toxic effects of 5 -fluorouracil in male germline cells of Swiss mice. J Exp Clin Cancer Res. 2002;21(2):277-82

31. Palo A K, Sahu P, Choudhury R C. Etoposide-induced cytogenotoxicity in mouse spermatogonia and its potential transmission. J Appl Toxicol. 2005;25(2):94-100.

32. Alam S S., Hafiz N A., Abd El-Rahim A H. Protective role of taurine against genotoxic damage in mice treated with methotrexate and tamoxfine. Environ Toxicol Pharmacol. 2011;31(1):143-52.
33. Geriyol P., Basavanneppa H.B., Dhananjaya B.L. Protecting effect of caffeine against vinblastine (an anticancer drug) induced genotoxicity in mice. Drug Chem Toxicol. 2015;38(2):188-95.

34. Melek F R, Aly F A, Kassem I A, Abo-Zeid M A, Farghaly A A, Hassan Z M Three further triterpenoid saponins from Gleditsia caspica fruits and protective effect of the total saponin fraction on cyclophosphamide-induced genotoxicity in mice. Z Naturforsch C, 2015;70 (1-2):31-7.

35. Afsar T, Razak S, Almajwal A. Acacia hydaspica ethyl acetate extract protects against cisplatin-induced DNA damage, oxidative stress and testicular injuries in adult male rats. BMC Cancer. 2017;17(1):883.

36. Karin M, Cao Y, Greten F R, Li ZW. NF-KB in cancer: From innocent bystander to major culprit. Nat Rev Cancer. 2002;2(4):301-10.

37. Oeckinghaus A, Ghosh S. The NF-KB family of transcription factors and its regulation. Cold Spring Harb Perspec Biol. 2009;1(4):a000034.

38. Schreck R, Rieber P, Baeuerle P A. Reactive oxygen intermediates as apparently widely used messengers in the activation of NF-kB transcription factor and HIV1. EMBO J. 1991;10 (8):2247-58.

39. Schreck R, Meier B, Mannel D N, Droge W, Baeuerle B A. Dithiocarbamates as potent inhibitors of nuclear factor $k B$ activation in intact cells. J Exp Med. 1992;175(5):1181-94.

40. Quintanilha J C F, de Sousa V M, Visacri M B, Amaral L S, Santos R M M Zambrano T, Salazar L A, Moriel P. Involvement of cytochrome P450 in cisplatin treatment: implications for toxicity. Cancer Chemother Pharmacol. 2017;80(2):223-33.

41. Schwarz M A, Lazo J S, Yalowich J C, Allen W P, Whitmore M, Bergonia $H$ A, Tzeng E, Billiar T R, Robbins P D, Lancaster J R. Jr, et al. Metallothionein protects against the cytotoxic and DNA-damaging effects of nitric oxide. Proc Natl Acad Sci U S A. 1995;92(10):4452-6.

42. Leung $A$ Y, Foster S. Encyclopedia of Common natural ingredients- second edition, John Willey \& Sons Inc, New York: 1996.

43. Cirico T L, Omaye ST. Additive or synergetic effects of phenolic compounds on human low density lipoprotein oxidation. Food Chem Toxicol. 2006;44(4):510-6.

44. Vinson J A, HaoY, Su X, Zubik L. "Phenol antioxidant quantity and quality in foods: vegetables," Journal of Agricultural and Food Chemistry. 1998;46(9):3630-4.

45. Arvaniti O S, Samaras Y, Gatidou G, Thomaidis N S, Stasinakis A S. Review on fresh and dried figs: Chemical analysis and occurrence of phytochemical compounds, antioxidant capacity and health effects. Food Res Int. 2019;119:24467.

46. Glei M, Pool-Zobel B L. The main catechin of green tea, (-)-epigallocatechin-3gallate (EGCG), reduces bleomycin-induced DNA damage in human leucocytes. Toxicol In Vitro. 2006;20(3):295-300

47. Kim E S, Kim D Y, Lee JS, Lee H G. Mucoadhesive chitosan-gum arabic nanoparticles enhance the absorption and antioxidant activity of quercetin in the intestinal cellular environment. J Agric Food Chem. 2019;67(31):8609-16.

48. LiY, Tian Q., Li Z, Dang M, Lin Y, Hou X. Activation of Nrf2 signaling by sitagliptin and quercetin combination against $\beta$-amyloid induced Alzheimer's disease in rats. Drug Dev Res. 2019;80(6):837-45.

49. Shokoohinia Y, Rashidi M, Hosseinzadeh L, Jelodarian Z. Quercetin-3-O- $\beta$-D glucopyranoside, a dietary flavonoid, protects $\mathrm{PC} 12$ cells from $\mathrm{H}_{2} \mathrm{O}_{2}$-induced cytotoxicity through inhibition of reactive oxygen species. Food Chem. 2015;167:162-7.

50. Jung H A, Kim J E, Chung H Y, Choi J S. Antioxidant principles of Nelumbo nucifera stamens, Arch Pharm Res. 2003;26(4):279-85.

51. Soliman N.A., Abd-Ellatif R.N., ELSaadany A.A., Shalaby S.M., Bedeer A.E. Luteolin and 5-flurouracil act synergistically to induce cellular weapons in experimentally induced Solid Ehrlich Carcinoma: Realistic role of P53; a guardian fights in a cellular battle. Chem Biol Interact. 2019;310:108740.

52. Damjanić A, Akacić B. Furocoumarins in Ficus carica. Planta Med 1974;26(2):119-23.

53. el-Kholy I S, Shaban M A. Constituents of the leaves of Ficus carica L. II. Isolation of a psi-taraxasteryl ester, rutin, and a new steroid sapogenin. J Chem Soc Perkin 1966;1,13:1140-2.

54. Teixeira D M, Patão R F, Coelho A V da Costa C T. Comparison between sample disruption methods and solid-liquid extraction (SLE) to extract phenolic compounds from Ficus carica leaves. J Chromatogr A. 2006;1103(1):22-8. 


\section{GRAPHICAL ABSTRACT}
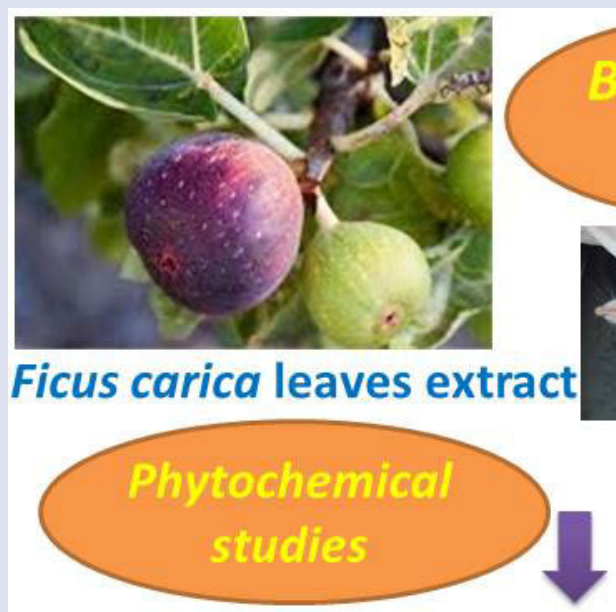

\section{Chromatographic investigation}

\begin{tabular}{|c|}
\hline 1 \\
\hline 2 \\
\hline 3 \\
\hline 4 \\
\hline 5 \\
\hline 6 \\
\hline
\end{tabular}

Chlorogenic acid

\section{Catechin}

Quercetin

Histopathological studies

Quercetin-3-O- $\beta$-D-glucopyranoside Kaempferol-3-O- $\beta$-D-glucopyranoside Luteolin-8-C- $\beta$-D-glucopyranoside

\section{ABOUT AUTHORS}

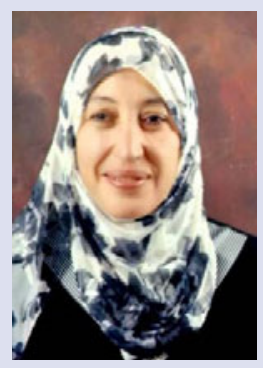

Dr. Maha Aly Fahmy Professor Emeritus

Ph.D. Degree in Cytogenetics, Faculty of Science, Ain Shams University, 1990.

Editor of the book "Basic of Genetic Science" in Arabic language, 2012, International number: 977-105082-5, Editor of the book "Population Genetics" in Arabic language, 2014, International number: 978 977-10-2947

Reviewer in the International Journal of Hazardous Materials (Elsevier), Reviewer to Scientific thesis at Faculty of Science, Ain Shams University, Cairo, Egypt.

Laboratory Skills: Chromosomal Aberration Assay, Sister Chromatid Exchange Assay Micronucleus Assay, DNA Fragmentation, Morphological Sperm Abnormalities, Comet Assay, DNA Isolation, PCR reaction and Real time PCR and their applications.

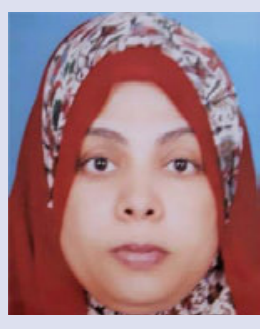

\section{Dr.Entesar El-sayed Hassan}

She works as a researcher in Genetics and Cytology department, National Research Center, Cairo, Egypt. She received her BSc. and M.Sc. from Faculty of Scince, Alazhar University. She also received her Ph.D.from Faculty of Scince, Ain Shams University.

Laboratory skills: Chromosomal Aberration Assay, Sister Chromatid Exchange Assay, Micronucleus Assay, DNA Fragmentation, Morphological Sperm Abnormalities, Comet Assay, Real time PCR and Data Analysis, Application of Bioinformatics

E-mail: entesarhassen@yahoo.com 


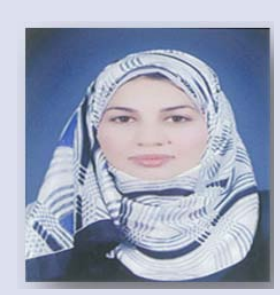

Dr. Noha E I-Sayed Ibrahim completed her PhD in 2016 from faculty of science, Zagazig University, Egypt. Currently she is working as a researcher at National Research Center (Egypt), Microbial Biotechnology Department, Genetic Engineering and Biotechnology Division. She has active participation in several national projects. She had published several articles in peer-reviewed good impacted international journals.

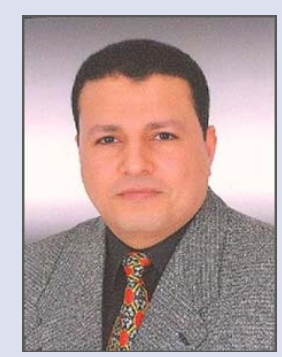

\section{Dr.E mad E I-Din M ohamed M ohamed Hassan}

Prof.Dr. of Chemistry of Medicinal \& Aromatic Plants. Head of Medicinal \& Aromatic Plants Research Dept., Pharmaceutical \& Drug Industries Research Division National Research Centre, Cairo, Egypt.

Area of Scientific Activities: Isolation and identification of the natural compounds of medicinal and aromatic plants adopting modern methods of analyses, addition to the evaluation of these active constituents biologically.

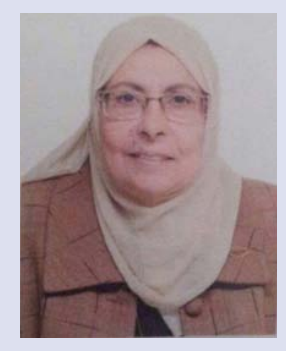

\section{Dr. Zeinab M ohammed Hassan}

Current Position: Researcher of Chemistry of natural Compounds, Chemistry of Natural Compounds Department, Pharmaceutical and Drug Industries Research Division, National Research Centre, Egypt. Research Interest: Cytogenetic research.

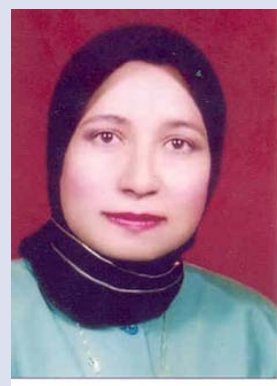

Prof. Dr. E nayat A bdel A ziz M ohamed O mara work as a researcher in Pathology Department, Medical Division, National Research Centre,Cairo, Doctor of Philosophy (Histology, Histochemistry \& Cytochemistry) .Faculty of Science, Cairo University, Giza. Egypt.She undertook doctoral scholarship at University of Leipzig, Institute of Biochemistry, Germany, (1999-2001).

Laboratory skills:

Histopathological, histochemical, Immunohistochemistry techniques and applications. Electron Microscopy (Techniques \& Interpretation). Applications and Uses of the Image Analysis System in Histopathology. Bioactive Natural Products and its Pharmacological Evaluation.

E-mail: eomara67@hotmail.com

Cite this article: Fahmy MA, Hassan EE, Ibrahim NE, Hassan EM, Hassan ZM, Omara EA. Protective Role of Ficus carica Extract Against Hepato-Testicular Side Effects and Genotoxicity Induced by Cisplatin. Pharmacogn J. 2020;12(3):645-56. 